\title{
内視鏡的摘除後に特異な再発形態を呈した直腸 $\mathrm{sm}$ 癌の 1 例
}

\author{
南盛一 山本康弘 小林達男河野透 \\ 小林病院外科, 旭川医科大学外科学講座消化器病態外科学分野1)
}

症例は 84 歳の女性. 直腸ポリープに対しポリペクトミーを施行し, 病理組織学所見は高分化型腺癌で sm1, ce (+), ly0, v0 であったが, 高齢のため経過観察としていた. しかし， 3 年目以降大腸スクリー ニングは行っていなかった. 約 10 年後, 便秘, 下血が続き当科受診. 直腸指診で下部直腸に全周性の壁硬 化を触知し，大腸内視鏡検査では表面は顆粒集簇様，敷石状の粘膜下腫瘍を呈した肚門縁から約 $15 \mathrm{~cm}$ にわたる全周性の狭窄をみとめた．生検では Group 4 であり，直腸癌 Rb, circ, A, N0, M0, cStageII の診断でマイルズ手術を施行した. 病理組織学所見は粘膜下のリンパ管内病変が主体の高分化腺癌で, 大 腸取扱い規約に従うと, RbPRa, circ, type4, 18.0×8.5cm, well, pA, ly3, v0, pN3, M1 (No 216), fStageIVであった.これは, ポリペクトミーの際にリンパ管内に遺残した癌細胞が粘膜下のリンパ管を腸 管軸方向に進展し，広範な敷石状の粘膜下腫瘍の形態を呈したと考えられた。

索引用語：直腸粘膜下浸潤癌, ポリペクトミー, 局所再発

緒言

近年, 本邦での大腸癌罹患率が上昇し, 早期癌で 見つかる症例もそれにともない増加してきた.また， ESD に代表される内視鏡治療の進歩, 適応拡大によ り $\mathrm{sm}$ 癌に対する内視鏡切除の機会が増え, それに ともない局所再発例も増加することが危惧されてい $ろ^{1-5)}$.

今回, 直腸 $\mathrm{sm}$ 癌に対する内視鏡治療後 10 年を経 て発見され，特異な形態を呈した局所再発の 1 例を 経験したので報告する.

\section{症例}

症例 : 84 歳, 女性.

主訴 : 便秘.

現病歴：平成 17 年 12 月より便秘, 下血を自覚し ていたが, 症状が続くため平成 18 年 2 月に当科を受 診. 直腸指診にて下部直腸に全周性の壁の硬化を触 知し, 直腸癌を疑い精査加療目的に当科入院となった.

既往歴 : 平成 7 年 3 月下部直腸の Isp 型ポリープ に対してポリペクトミーを施行. 病理組織学所見は 高分化腺癌で深達度は sm1, 脈管侵襲は陰性, 断端 までの距離は $0.5 \mathrm{~mm}$ 未満であった。また, 両側変形
性膝関節症にて平成 13 年より車椅子移動となって いる.

入院時現症 : 身長 $141 \mathrm{~cm}$, 体重 $41 \mathrm{~kg}$, 眼球結膜に 貧血なし. 腹部：軟, 腫瘤は触知しなかった. 体表 : 鼠径を含め，表在リンパ節を触知しなかった。直腸 指診 : 下部直腸から肛門にかけて全周性の壁の硬化 を触知した。

入院時血液検査所見 : 末梢血液に異常は認めな かったが, 生化学検査で LDH が $563 I U / 1$ と軽度上 昇していた，腫瘍マーカーは CEA が $205.3 \mathrm{ng} / \mathrm{ml}$ と著明に上昇していた。

注腸造影検查（図 1)：Ra から Rbにかけて約 15 $\mathrm{cm}$ にわたり全周性の狭窄をみとめた。

胸部 CT 検査 : 肺転移は認めなかった.

腹部 CT 検査 (図 2)：下部直腸の壁肥厚, 辺縁の毛 羽立ちを認めたが, 周囲藏器への浸潤は認めなかっ た。また，肝転移，腹水はなく，リンパ節腫大も認 めなかった。

大腸内視鏡検査（図 3)：表面は顆粒集簇様，敷石 状で, 粘膜下腫瘍の形態を呈し, 肛門縁から約 $15 \mathrm{~cm}$ にわたり全周性の狭窄をみとめた。生検の結果，表 層のごく一部に小腺腔を形成しつつ増殖する異型腺 管の増生を認め, 高分化型の腺癌が疑われた. 


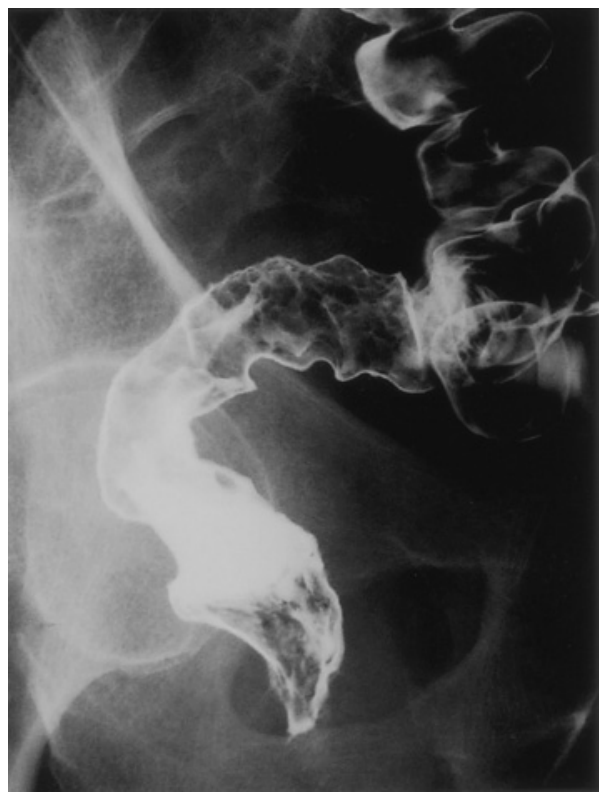

図 1 注腸造影検査: 直腸 $\mathrm{Ra}$ から $\mathrm{Rb}$ にかけて約 $15 \mathrm{~cm}$ にわたり全周性に壁の不整像と狭窄をみ とめた。

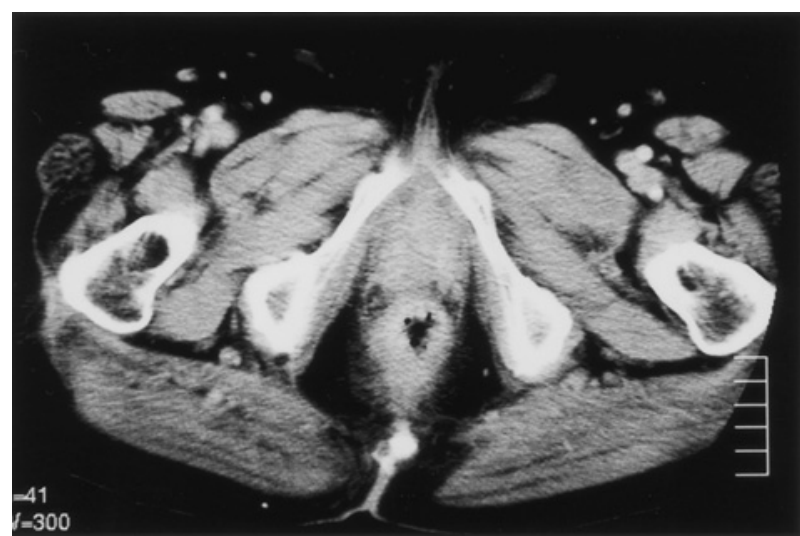

図 2 腹部造影 $\mathrm{CT}$ 検査：下部直腸の壁肥厚, 辺縁の毛羽立ちを 認めたが, 周囲臓器への浸潤は認めなかった。

手術所見（図 4）: 平成 18 年 3 月 2 日，直腸 癌 Rb, circ, A, N0, M0, cStage II の診断のもと, マイルズ手術（D3）を施行した。肝転移，腹水は認

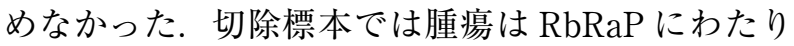
全周性で，顆粒集簇様で敷石状を呈していた。大き さ $9.0 \times 15.0 \mathrm{~cm}$ で深達度は A，251 番リンパ節に腫 大が認められ転移が疑われた。

病理組織学所見（図 5)：腫瘍は粘膜下腫瘍様の増 殖を示し，かつリンパ管内での増殖が大部分を占め る高分化腺癌で，肉眼的に認められた結節性増殖は リンパ管内の腫瘍増殖を反映したものと考えられ た．また, 深達度は pA で 1 群〜 3 群およびサンプリ

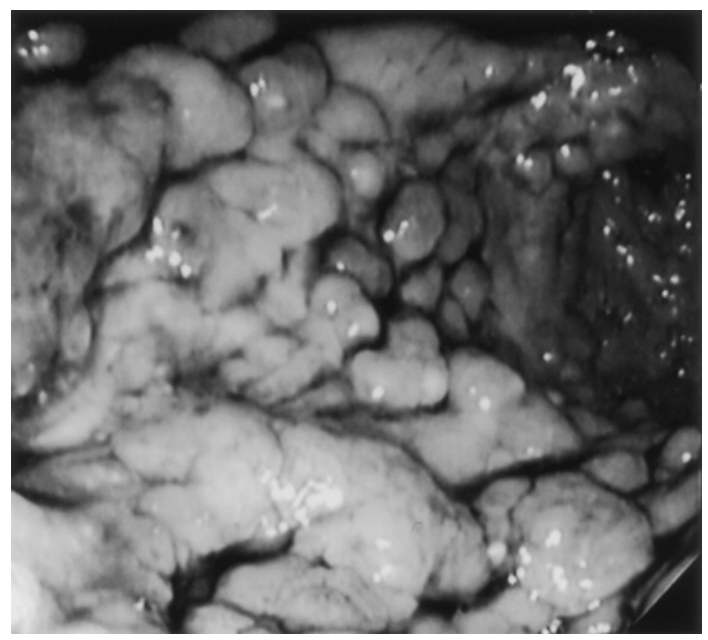

図 3 大腸内視鏡検査: 表面は顆粒集簇様, 敷石状で, 広 範囲の粘膜下腫瘍の形態を呈していた.

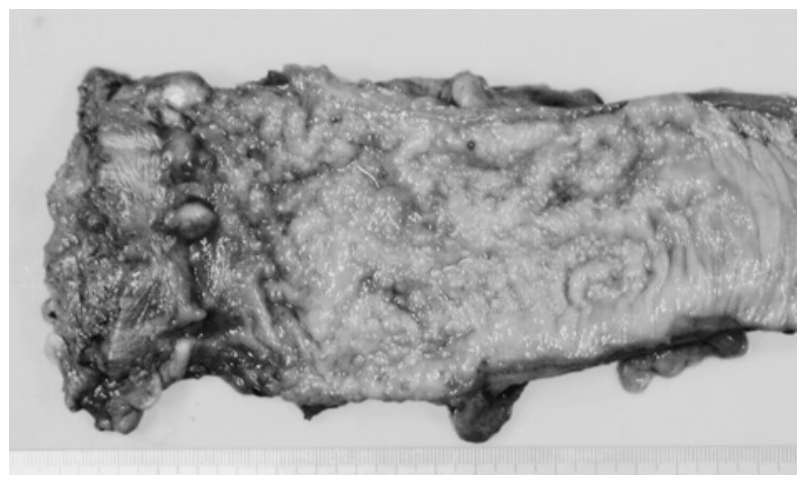

図 4 切除標本

腫瘍は広範囲の粘膜下腫瘍の形態で無数の結節が集簇してみられ た. RbPRa, circ, type4, $18.0 \times 8.5 \mathrm{~cm}, \mathrm{~A}, \mathrm{~N} 1, \mathrm{H} 0, \mathrm{P} 0$, sStageIIIa

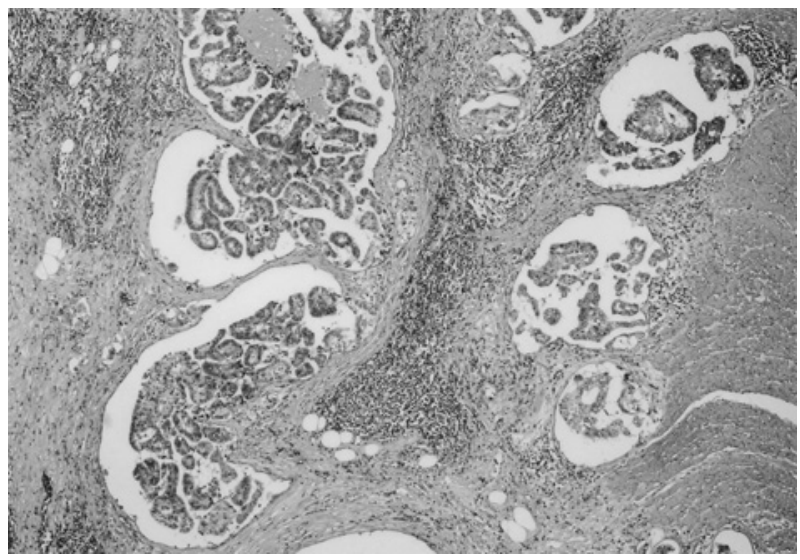

図 5 病理組織学所見 $($ HE. $\times 4)$

腫瘍は粘膜下腫瘍様の増殖を示し，かつリンパ管内での増殖が大 部分を占める高分化腺癌であった。 


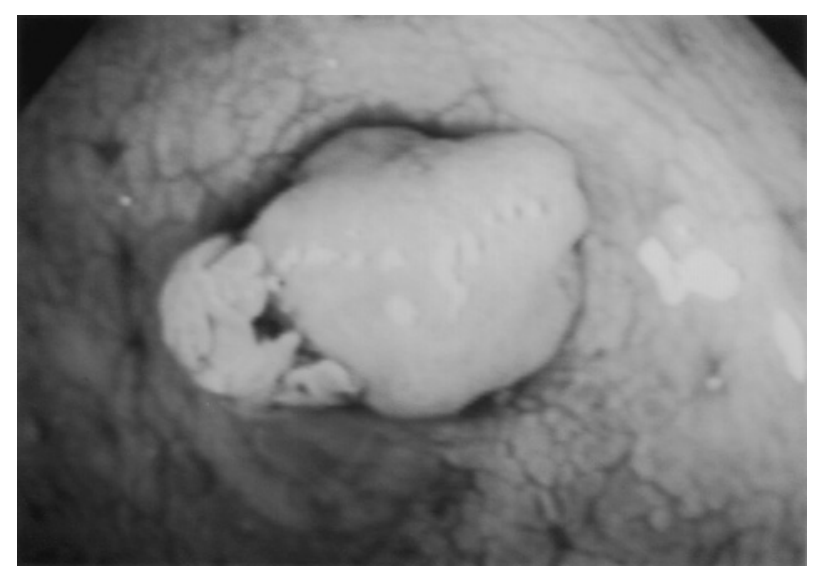

図 6 a) 初発時内視鏡所見 直腸 $\mathrm{Rb}$ に Isp 型ポリープをみとめた.

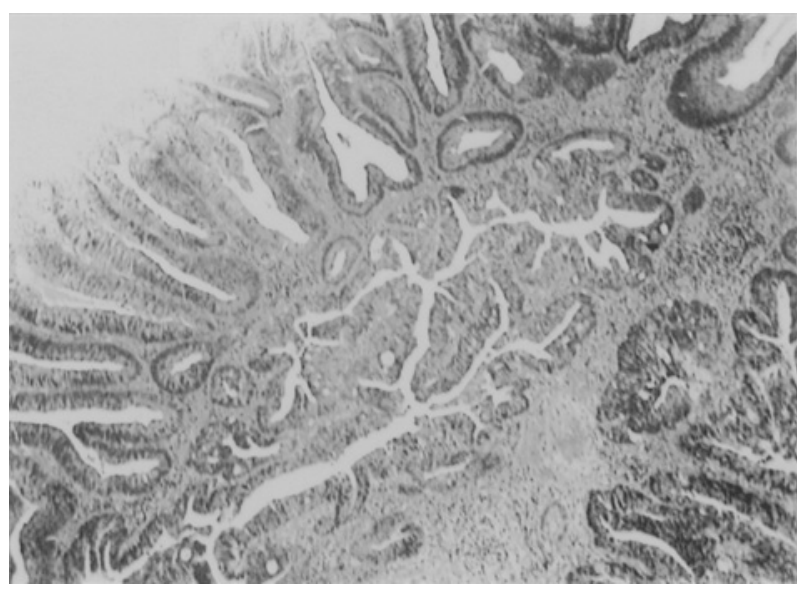

図 6 b) 病理組織学所見 $($ HE. $\times 4)$

高分化腺癌で深達度は sm1, 脈管侵襲は陰性であったが, 断端ま での距離は $0.5 \mathrm{~mm}$ 未満であった.

ンパ管侵襲陰性であったが局所再発しており，病理 組織学所見も粘膜下の拡がりが強い進展形式を示し リンパ管侵襲も陽性であった. 同様に, 井上ら ${ }^{11}$ が報 告した 4 例の局所再発例のうちの 2 例も粘膜下腫瘍 様の内視鏡所見を呈しており, 石川ら ${ }^{122}$ は大腸 $\mathrm{sm}$ 癌内視鏡摘除の局所再発の内視鏡所見として粘膜下 腫瘍様所見に注意すべきであると報告している，再 発までの期間は内視鏡切除後 3 力月から 5 年までの 報告6,11) がほとんどであるが，6 年以上経過して再発 している症例も報告されている ${ }^{13,14)}$.これまで諸家 により多くの大腸 $\mathrm{sm}$ 癌内視鏡摘除後再発例が報告 されているが, 医学中央雑誌を使用し 1997 年から 2006 年の報告例について key word「直腸癌」「内視 鏡治療」「局所再発」で検索し得た範囲では本症例の 様に広範に進展し特異な形態を呈している報告はない．

本症例はポリペクトミー後 10 年を経て進行癌で 見つかっており，術後サーベイランスに関して反省 すべき症例である. 大腸癌取扱い規約 $(\text { 第 } 6 \text { 版 })^{15}$ に は大腸 $\mathrm{sm}$ 癌の内視鏡摘除後にリンパ節郭清を含む 追加腸切除を行う条件が示されている.「明らかな脈 管内癌浸潤」「低分化腺癌」「断端近傍までの massive な癌浸潤」のうち 1 項目以上が存在することとある が，本症例には「断端近傍までの massive な癌浸潤」 があてはまる，通常よりも厳重なフォローアップが 必要であったが, それを行うことができなかったの は悔やまれる。

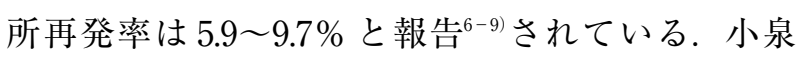
$ら^{10)}$ は 93 例中 6 例の局所再発を報告しているが， 6 例中 4 例については本症例同様に内視鏡切除時のリ 


\section{結語}

今回, 直腸 $\mathrm{sm}$ 癌に対する内視鏡治療後 10 年を経 て発見され，特異な形態を呈した局所再発の 1 例を 報告した。内視鏡摘除後の大腸 $\mathrm{sm}$ 癌サーベイラン スは厳重に行い, 根治的切除が可能な時期に再発を 発見することが必要であると思われるが, サーベイ ランスの期間，方法などに関するエビデンスがない のが現状である。内視鏡摘除後の病理組織学所見の 評価を的確に行い, 個々の症例に応じてサーベイラ ンスプログラムを計画することが必要であると思わ れた。

\section{謝辞}

稿を終えるにあたり, 本症例の病理組織学所見に関する御 指導頂いた札幌医科大学病理学第一講座の田村保明先生に 深謝いたします。

\section{参考文献}

1) Yamamoto H, Koiwai H, Yube $T$, et al : A successful single-step endoscopic resection of a 40 millimeter flatelevated tumor in the rectum : endoscopic mucosal resection using sodium hyaluronate. Gastrointest Endosc $50: 701-704,1999$

2）田中信治, 岡 志郎, 茶山一彰ほか：表面型早期大腸癌 の内視鏡的粘膜切除術一適応 - 切除手技選択と治療成 績一. Gastroenterol Endosc 46 : 243-252, 2004

3）田中信治, 岡 志郎, 金子 嚴ほか：外科治療 内視鏡 切除一ポリペクトミー, EMR, ESD一. 消化器外科 28 : 826-833, 2005
4) Yahagi N, Fujishiro M, Imagawa A, et al : Endoscopic submucosal dissection for the reliable en bloc resection of colorectal mucosal tumors. Dig Endosc 16 (Suppl) : S89-S92, 2004

5）為我井良郎, 後藤亮子, 永田尚義ほか：Endoscopic submucosal dissection (ESD) による大腸腫瘍一括切除の意 義と問題点. 消化器医学 $3: 57-64,2005$

6）古澤元之助：内視鏡的ポリペクトミーが行われた大腸 sm 癌患者の予後. 胃と腸 $20: 1087-1094,1983$

7）武藤徹一郎：「大腸 sm 癌」主題症例をみて. アンケート 集計とその考察. 胃と腸 $18: 851-855,1983$

8）柴藤和久, 富樫一智, 柏木 宏ほか: 内視鏡的に摘除さ れた大腸 sm 癌の長期予後に関する検討. Prog Dig Endosc 50 : 92-95, 1997

9）横山 正, 横田敏弘, 斉藤大三ほか: 再発例からみた大 腸 sm 癌の内視鏡治療とそのフォローアップ. Therap Res 18:359-361, 1997

10）小泉浩一，風見 明，服部公昭ほか：大腸 $\mathrm{sm}$ 癌内視鏡 治療後の至適サーベイランス間隔とその modality一再 発例の転移様式から一。消化器内視鏡 18:337-346, 2006

11）井上雄志，斉田 真，刈部豊彦ほか：大腸 $\mathrm{sm}$ 癌内視鏡 治療後の遺残再発の実態とその治療. 消化器内視鏡 $18: 347-354,2006$

12）石川 勉, 牛尾恭輔, 宮川国久ほか：大腸ポリペクト ミー後の局所再発病変の特徵. 胃と腸 $28: 511-522$, 1993

13）横山 正, 横田敏弘, 斉藤大三ほか：内視鏡的ポリペク トミー 6 年 6 か月後に局所再発をきたした大腸粘膜下 浸潤癌の 1 例. Prog Dig Endosc 46 : 194-195, 1995

14）柏木亮一, 藤盛孝博, 森下 透ほか：ポリペクトミー後 6 年で局所再発が認められた Ip 型 sm 癌の 1 例. 消化器 内視鏡 6:1499-1503,1994

15）大腸癌研究会 (編)：大腸癌取扱い規約. 第 6 版. 金原出 版, 東京, 1998 


\title{
A Case of Local Recurrence Ten Years after Polypectomy for Submucosal Rectal Cancer
}

\author{
S. Minami, Y. Yamamoto, T. Kobayashi, and T. Kono* \\ Department of Surgery, Kobayashi Hospital, \\ *Department of Surgery, Division of Gastroenterology, Asahikawa Medical College
}

An 84-year-old woman had received polypectomy for a rectal polyp. The lesion was identified to be a welldifferentiated adenocarcinoma invading the submucosa with cut end of greater than $0.5 \mathrm{~mm}$ and no vessel invasion. She did not receive screening examination of the colorectum for a further 3 years. About 10 years later, being conscious of constipation and melena, she consulted our department. Digital examination revealed wall hardening in the whole lower rectum. Stenosis with innumerable small nodules on the surface was observed over $15 \mathrm{~cm}$ from the anal verge by colonofiberscope. The biopsy results suggested rectal cancer. We diagnosed it as rectal cancer, and performed Miles' operation. Pathological examination showed that a well-differentiated adenocarcinoma existed mainly in the submucosal lymph duct. We strongly suspect that this peculiar configuration was formed by the remnant cancer spreading horizontally in the submucosal lymph duct. 